\title{
Information Disclosure and its Determinants on Lithuanian Companies' Websites: A Quantitative Approach
}

\author{
Kristina Kundeliene, Agne Stepanauskaite
}

\author{
Kaunas University of Technology \\ K. Donelaicio st. 73, LT-44029, Kaunas, Lithuania \\ E-mail.kristina.kundeliene@ktu.lt,agne.stepanauskaite@gmail.com \\ cross $^{\text {ref }} \underline{\text { http://dx.doi.org/10.5755/j01.ee.29.4.17271 }}$
}

\begin{abstract}
Nowadays, the issue of stakeholders' effective decision-making has become increasingly important. In most cases the information, provided in financial statements, is not sufficient to make decisions, thus the importance of voluntarily disclosed information increases. The Internet and companies' websites may serve as a vehicle for the provision of such information. Therefore, the purpose of the article is to measure the extent of voluntary information disclosure on the websites of Lithuanian companies and to investigate whether there is a significant association between theoretically possible disclosure determinants. Research methods used in the study are the following: comparative analysis of scientific literature, logical, systematic analysis, content analysis using scope and quantity index approaches and correlation analysis using Spearman's rank correlation coefficient. Results showed a statistically significant connection between the company's size (as determined by its earnings) and the company's voluntary information disclosure index. The companies with higher earnings are inclined to provide a wider scope and a larger volume of information. Furthermore, the connection between the number of employees and the word quantity index wasn't established. This research adds to the samples of previous studies and analyses disclosure of financial and non-financial information on companies' websites.
\end{abstract}

Keywords: Voluntary Information Disclosure; Corporate Disclosure; Agency Theory; Signaling Theory; Financial Information; Non - Financial Information.

\section{Introduction}

Corporate disclosure is one of the essential elements for the functioning of an efficient capital market. Nowadays, having only mandatorily provided information is not enough to make effective stakeholders' decisions, and that leads to growing value of voluntarily provided information (Ceustermans \& Breesch, 2017; Alfaraih \& Alanezi, 2011). Operations, activities and proceeds of the companies' activities are significant to investors, creditors, analysts, consumers and other stakeholders who seek greater transparency, more accurate and timely gained information. Information asymmetry for stakeholders could be reduced by voluntary information disclosure (Cassar et al., 2015) that is essential in obtaining the trust of the individuals, who are interested in the activity of the company (Dagiliene et al., 2014).

In the recent years, institutional pressure on businesses to disclose true, correct and complete information became significantly stronger (Gisbert \& Navallas, 2013). Despite the increasing requirements for the quality of the companies' mandatorily provided information, a big part of the companies' information isn't mandatory to disclose and could be provided, if a company does want to, only on the voluntary basis. That is the reason why voluntary disclosure aspect is becoming more and more important in both financial statements of a company and other information sources, such as companies' websites.

According to Sommer et al. (2014), the Internet is an alternative source of financial information and an important channel of corporate social responsibility information.
Stakeholders, such as customers and potential employees, use the company's website to get information about the activities of social responsibility that were initiated at a chosen company. Usage of websites enables stakeholders to reach needed information without intermediaries (see Carroll, 2011). Compared to printed financial statements, access to such documents on the Internet increases availability and timeliness of financial information. There is a necessity for the analysis of reasons that determine a company's behavior and its decision to voluntarily disclose information. Such analysis could reveal some additional information about the company. Finally, only the company itself decides what additional voluntary information to disclose.

Authors who analysed the disclosure practices within large companies on the subject are Binh (2012), Alhazaimeh et al. (2014), and Zhang \& Zhang (2014a, 2014b). The situation in small companies was analyzed by Ceustermans and Breesch (2017), Kitching et al. (2011), and Collis (2012). The practice of voluntary information disclosure on the internet was analyzed by Ghasempour and Yusof (2014), Basuony and Mohamed (2014), Alali and Romero (2012), DAmaso and Lourenço (2010), Pozniak (2015), and Sommer et al. (2014). Even though the voluntary disclosure of information has been analyzed thoroughly, there has not been much research done on voluntary information disclosure of Lithuanian companies on their websites. Research on the Internet - as a medium for shared information - allows one to assess companies' transparency. Furthermore, it enables one to visualize the view of a company on publishing important information necessary for 
Kristina Kundeliene, Agne Stepanauskaite. Information Disclosure and its Determinants on Lithuanian Companies'....

shareholders (see Legenzova \& Jovaisaite, 2014). Lithuanian authors, having social responsibility as the subject, analyzed voluntary disclosure of information of the largest and the most active companies. The analysis of companies' published social information, their annual reports and explanatory notes have been performed by Dagiliene and Bruneckiene (2010); Dagiliene and Gokiene (2011) and Leitoniene and Sapkauskiene (2012) analyzed the reports of the disclosure of information of social responsibility. Leitoniene and Sapkauskiene (2015) published an assessment of the quality of social responsibility in annual reports and the information on companies' websites.

There is a fundamental economic problem of information asymmetry, caused by insufficient supply of information to the society and interest groups by the companies. As per previous research, in most of the analyzed cases, companies are not willing to provide more information than it is mandatory by law. The importance of this problem should be taken more into account by researchers, and it should be analyzed more deeply. There is still a lack of extensive research done on the information disclosure on the websites, especially in small and mediumsized Lithuanian companies. Consequently, it would be appropriate to analyze the practice of voluntary disclosure of information and its determinant factors in 1000 largest Lithuanian companies' websites. The reason for this suggestion is that some companies provide more information than others, it is important not only to analyze the quantity of disclosed information but also to find out what determines the differences of information disclosure on the websites among companies in Lithuania and draw conclusions, which could give broader understanding of the economic relations between characteristics of Lithuanian companies and their information disclosure. Also at some point it could reveal companies' perception on their interest groups' needs related to information disclosure.

Scientific problem analyzed in this article: what factors determine information disclosure (financial and nonfinancial) on the websites of Lithuanian companies?

The objective of the article is to measure the extent of voluntary information disclosure on the websites of Lithuanian companies and to investigate whether there is a significant association between theoretically possible disclosure determinants.

Information disclosure research involved the application of the following methods: logical, systematic and comparative analysis of scientific literature, content analysis using scope and quantity index approaches, correlation analysis using Spearman's rank correlation coefficient.

The contribution of this paper to the existing literature is twofold. Firstly, the paper contributes to the existent literature expanding the knowledge on the relationship between the level of corporate disclosure and its determinants. Secondly, the paper adds to reducing the gap of studies on Lithuanians companies' disclosure practice on the Internet.

The rest of the paper is organized into five parts. Section 2 reviews the literature related to our research. In section 3 , the theoretical framework and research hypotheses are formed. Section 4 describes the research methodology. Section 5 presents and discusses the results, and section 6 concludes the paper.

\section{Previous Research on Voluntary Disclosure Factors}

Due to the differences in publishing of information in various sources, for this study have chosen following sources: companies' social reports, annual notes and websites. Authors, such as Ghasempour and Yusof (2014), Basuony and Mohamed (2014), Alali and Romero (2012), DAmaso and Lourenço (2010), and Pozniak (2015) have analyzed the practice of companies' voluntary information disclosure on the Internet. Even though the main source of information were companies' annual reports, the importance of the information on websites and social network has increased greatly. The information on social networks and websites allows a company to share its financial results, particular decisions and the vision of the company to the wide circle of company's stakeholders.

Previous studies analyzing information disclosure on the Internet can be divided into two groups: descriptive theoretical studies (study of the largest 100 Lithuanian companies - transparency aspect, written by Legenzova and Jovaisaite (2014), and analytical studies that are intended to identify characteristics of voluntary information disclosure. These also evaluate the causal relationship between voluntary information disclosure and disclosure determinants (see Pozniak, 2015; Damasio \& Lourenco, 2010; Ghasempour \& Yusof, 2014; Basuony \& Mohamed, 2014) and the relationship between voluntary disclosure and the consequences for companies or for the market (for example, Feleagă and Dragomir (2012)).

According to Prince and Dwivedi (2013), studies of the information disclosure influence on company's results, provided final, reasoned conclusions, and to date there is no consensus reached about the factors determining a voluntary disclosure.

Table 1 presents determinants which influence voluntary information disclosure that were most frequently analysed in previous scientific literature on voluntary information disclosure. Disclosure factors chosen for analysis of disclosure in annual reports and websites usually are the same.

Table 1

Information Disclosure factors Analyzed in Previous Studies (Made by the Authors)

\begin{tabular}{|c|c|}
\hline Factor & $\begin{array}{l}\text { Authors, who analysed the influence of disclosure } \\
\text { factors }\end{array}$ \\
\hline Company’s size & $\begin{array}{l}\text { Basuony \& Mohamed (2014); Pozniak (2015); Barac et } \\
\text { al. (2014); Juhmani (2014); Ghasempour \& Yusof } \\
\text { (2014); Hossain et al. (2012); Dagiliene \& Bruneckiene } \\
\text { (2010) }\end{array}$ \\
\hline Profitability & $\begin{array}{l}\text { Pozniak (2015); Gamerschlag et al. (2010); Juhmani } \\
\text { (2014); Siala et al. (2014); Ghasempour \& Yusof } \\
\text { (2014); Hossain et al. (2012); Alali \& Romero (2012) }\end{array}$ \\
\hline Company's age & $\begin{array}{l}\text { AbuGhasaleh et al. (2012); Juhmani (2014); Hossain et } \\
\text { al. (2012) }\end{array}$ \\
\hline $\begin{array}{l}\text { Ownership } \\
\text { concentration }\end{array}$ & $\begin{array}{l}\text { DAmaso \& Lourenço, 2010; Gamerschlag et al. (2010); } \\
\text { Siala et al. (2014); Ghasempour \& Yusof (2014) }\end{array}$ \\
\hline $\begin{array}{l}\text { Financial } \\
\text { leverage }\end{array}$ & $\begin{array}{l}\text { DAmaso \& Lourenço, 2010; Juhmani (2014); Siala et } \\
\text { al. (2014); Alali \& Romero (2012) }\end{array}$ \\
\hline Sector & $\begin{array}{l}\text { DAmaso \& Lourenço (2010); Gamerschlag et al. } \\
\text { (2010); Alali \& Romero (2012); Dagiliene \& } \\
\text { Bruneckiene (2010), Leitoniene \& Sapkauskiene (2012) }\end{array}$ \\
\hline Liquidity & Hossain et al. (2012) \\
\hline
\end{tabular}


In previous research for the analysis were chosen: 1) Company's full disclosure of information on the Internet (both financial and non-financial information), (see Ghasempour \& Yusof, 2014; Hossain et al., 2012; Siala et al., 2014; Alali \& Romero, 2012); 2) Only financial information voluntary disclosure on the internet (see Basuony \& Mohamed, 2014; Pozniak, 2015; Barac et al., 2014; Damasio \& Lourenco, 2010) 3) Social information disclosure (see Gamerschlag et al., 2010; Juhmani, 2014). The results of these studies are inconsistent. Some authors found a significant relationship between voluntary information disclosure and a certain company's characteristics, such as profitability (see Gamerschlag et al., 2010; Siala et al., 2014), and other authors found no significant relation.

Disclosure of information on the Internet has been analysed not only for listed companies, but also unlisted companies (see Bozcuk et al., 2011) in terms of financial disclosure on companies' websites. Unlisted companies, whose shares are not traded publicly, were analysed by Barac et al., (2014) in the case of the annual report analysis.

After analysis of Lithuanian scientific literature on voluntary information disclosure, it was found only a few authors who analysed the voluntary disclosure of information on the Internet. Legenzova and Jovaisaite (2014) analyzed mandatory and voluntary disclosure of financial and non - financial information on corporate websites in Lithuania in the context of their corporate transparency. Rudzioniene and Petraskaite (2014) analysed corporate social responsibility information disclosure on the Internet. Both those previous studies were only of general scope: they analysed the presence or absence of a certain type of information, without considering the quantitative aspect of disclosed information (for example, the number of sentences, words, etc.) presented. Leitoniene and Sapkauskiene (2015) created 15 criteria to assess the quality of companies' social responsibility information on the websites and in the annual reports. Studies on voluntary disclosure of financial information in the financial statements of Lithuanian companies were conducted by Legenzova (2008) and Dagiliene (2009). There is a lack of analysis on determinants of voluntary disclosure of information on different sources of information, such as companies' websites. Some authors are analysing only one particular group of voluntarily provided information (both in annual reports and in other sources of information) or all information divides into few separate groups of information because of differences existing between determinants of different types of disclosed information.

Some authors divide a company's disclosed information into different groups: strategic, financial, future - oriented information, social responsibility information, stock price information, etc. Nilehn (2014) analysed strategic information disclosure in the annual reports, and Barac (2012) sought to identify factors that determine disclosure of information about the company's cash flows. Meanwhile, Legenzova (2008) analyzed determinants of financial information disclosure.

Given the fact that the voluntary disclosed information is often concerning the economic, social and environmental aspects of company's activity, that are better known as elements of corporate social responsibility. Many authors analysed determinants of social responsibility disclosure
(Potrich et. al., 2017; Hamrouni et al., 2017; Zang \& Niu, 2015 etc.). This type of study in Lithuania was conducted by Dagiliene (2010), who analysed the practice of social responsibility information disclosure in annual reports of Lithuanian national socially responsible business network companies.

Thus, results of previous research on the assessment of voluntary information disclosure determinants are inconsistent and there is a need for more detailed research in different countries, including Lithuania. It can be stated that there is a lack of studies in Lithuania analysing a wider range of characteristics that could influence disclosure of information related to corporate social responsibility and other in the future - oriented information on the Internet (e.g. is not mandatory to disclose forecasts for listed companies on the Internet, but it is important to provide information on the forecast implementation).

Building on the example of foreign studies (see Borbolla et al., 2005), it is important to carry out research aimed to determine factors of voluntary information disclosure of SME and determinants of information disclosure in separate sectors such as banking or the public sector. Such studies are needed because their results will provide additional insights into the voluntary disclosure practices of different operational activities and sizes companies, will help to decide about corporate transparency and thereby reduce information asymmetry.

\section{Theoretical Framework and Research Hypotheses}

According to Ghasempour and Yusof (2014), information disclosure is defined as the transmission and delivery of economic information related to the financial state and performance results (both financial and nonfinancial) of a company via quantitative and other forms. If information disclosure is compulsory for legal reasons, such revelation is termed mandatory information disclosure. If it is not required by any legal regulation, the term voluntary information disclosure is used.

Scientific literature analysis has shown that to interpret the factors of voluntary information disclosure, different theories can be combined. For instance, Broberg et al., (2009) used agency, signaling and capital need theories in order to examine the aspects of information disclosure. Furthermore, authors mention stakeholder, legitimacy, and institutional theories, which can be implemented for information disclosure analysis. In analytical literature about the factors of information disclosure four theories occur most frequently. These include agency, signaling, capital need and legitimacy theories. Other authors consider stakeholder theory being used most frequently as well (Kilic et al., 2013).

According to theoretical and empirical (as well as information disclosure factors of small and medium enterprises in Lithuania) research analysis, considering the lack of more detailed data about the information disclosure on the Internet of Lithuanian companies', hypotheses on voluntary information disclosure on the Internet among Lithuanian companies' are formulated. Hypotheses are formed for factors, which can be explained theoretically as well as whose influence on information disclosure is often analyzed in scientific literature. 
The size of a company. Hypothesis of political visibility approves that larger enterprises tend to be more visible than small ones. Due to this fact, large companies are inclined to provide more information (Basouny \& Mohamed, 2014). Moreover, as large companies are more complex than their small equivalents, stakeholder groups require more information to satisfy their demand. Another reason for the positive correlation between the size of a company and voluntary information provision is closely related to agency theory. According to Albitar (2015), it is possible that bigger companies frequently are inclined to provide more information in order to decrease the borrowing costs, which arise from the fact that major enterprises manage a larger part of external stock compared to minor ones. In previous research conducted by the mentioned authors, annual reports' analysis provided that the size of a company has a positive impact on information provision in annual reports (Albitar, 2015; Kilic et al., 2013; Soliman, 2013). Acknowledging information provision online, equal results are seen among preceding authors as well (Hossain et al., 2012, Ghasempour \& Yusof, 2014, Basouny \& Mohamed, 2014, Pozniak, 2015 and Barac et al., 2014). That is why, considering the results of many studies, it is possible to form the first hypothesis about the existing positive correlation between the extents of voluntary information provision in Lithuanian companies' online websites and the size of a corresponding enterprise. In the scientific literature, the size of a company is evaluated by various criteria: balance sheet assets availability (Basuony \& Mohamed, 2014; Pozniak, 2015; Barac et al., 2014), received income (Nilehn, 2014; Bhayani, 2012; Kilic et al., 2013; Broberg et al., 2010) or number of employees (Broberg et al., 2010; Jouirou \& Chenguel, 2014).

Considering the fact that authors such as Barac et al. (2014) and Broberg et al. (2009) have analyzed the impact of several criteria, which describe the size of a company, in order to assess company size influence on information provision, this research includes two hypotheses about the size of a company. Both are related to two separate criteria used in scientific literature to determine company size: number of employees and income.

$H_{1 A}$ : There is a significant positive relationship between company's number of employees and both financial and non - financial information disclosure on a company's website.

$H_{l B}$ : There is a significant positive relationship between a company's revenue and both financial and non - financial information disclosure on a company's website.

Company's profitability. Agent theory suggest that in order to show shareholders that executives are working for the good of the company and that they are deserved the compensation they are getting for day - to - day work, executives of profitable companies voluntarily disclose more information compared with less profitable ones (see Albitar, 2015). According to the signalling theory, profitable companies try to distinguish themselves from other less profitable companies by revealing more information, while less profitable ones try to conceal some part of the information.

Previous studies provide inconsistent results on Internet information disclosure impact on company's profitability.

Siala et al. (2014) in their study found a positive significant relation between a company's profitability and disclosure of financial and non-financial information on the Internet. Gamerschlag et al. (2010) found a positive relationship between company's profitability and the scope of voluntarily provided CSR information on the Internet, while authors such as Ghasempour and Yusof (2014), Hossain et al. (2012), Alali and Romero (2012), and Juhmani (2014) did not find a significantly relevant relation between a company's profitability and company's financial and non - financial information disclosure on the Internet. Previous research on disclosure of a company's information in the annual reports gave conflicting results. While Bhayani (2012), Albitar (2015) and Soliman (2013) found a significant positive relationship between a company's profitability and the volume of voluntarily provided information, other authors (see Kilic et al., 2013) didn't identify a significant relationship between those two sizes.

Because of conflicting results of previous studies and numerous studies submitting that profitability could be positively related to company's information disclosure (agent theory, legitimacy theory and signal theory that were applied to analyse information disclosure), the $\mathrm{H}_{2}$ hypothesis was developed suggesting presence of relationship between company's profitability and company's voluntary disclosure on its website.

$\mathrm{H}_{2}$ : There is a significant relationship between companies' profitability and the voluntary disclosure of financial and non-financial information on company's website.

Hannon (2014) claims that in order to implement their business strategy and to gain competitive advantage, "young" companies actively use new technologies. So, it is possible that "young" companies will be willing to disclose more information on a voluntary basis compared with old companies.

On the other hand, based on legitimacy theory company's information disclosure should be positively related to the company's age, because longer operating company should have a better reputation within society and be more involved in social activities than younger companies. The longer company operates, the more it needs to communicate with society and company's environment.

Negative relationship between company's age and disclosure of meaningful to the investors financial information provided on the Internet was found by AbuGhazaleh et al. (2012). While research of Hossain et al. (2012) didn't reveal that kind of relationship. Juhmani (2014) didn't find significant relationship between disclosure of social responsibility information on the Internet and company's age. Jouirou and Chenguel (2014) and Nandi \& Ghosh (2012) found a negative relation between voluntary information disclosure in the annual reports and company's age.

Hypothesis $\mathrm{H}_{3}$ was developed in the light of previous research results, and it found a significant relation between voluntary information disclosure and the age of the company. Existing relations could be explained mostly from the signaling theory point of view (see Hannon, 2014).

$H_{3}$ : There is a significant relationship between a company's age and voluntary disclosure of financial and non-financial information on a company's website. 
According to the hypotheses, there were selected measures to each of possible determinant of information disclosure (see Table 2).

Table 2

Factors Chosen for the Research

\begin{tabular}{|l|l|l|}
\hline \multicolumn{1}{|c|}{ Factor } & \multicolumn{1}{|c|}{ Measurement } & $\begin{array}{l}\text { Measurement used in previous } \\
\text { studies }\end{array}$ \\
\hline $\begin{array}{l}\text { Company's } \\
\text { size (a) }\end{array}$ & $\begin{array}{l}\text { Revenue (in 1000 } \\
\text { Euros) }\end{array}$ & $\begin{array}{l}\text { Nilehn (2014), Bhayani (2012), } \\
\text { Kilic et al. (2013) }\end{array}$ \\
\hline $\begin{array}{l}\text { Company's } \\
\text { size (b) }\end{array}$ & Number of employees & $\begin{array}{l}\text { Broberg et al. (2010), Jouirou \& } \\
\text { Chenguel (2014) }\end{array}$ \\
\hline Profitability & ROS=EBIT/SALES & $\begin{array}{l}\text { Bruslerie \& Gabteni (2014), } \\
\text { Bhayani (2012) }\end{array}$ \\
\hline Company's age & $\begin{array}{l}\text { Duration of company's } \\
\text { activity (years) }\end{array}$ & $\begin{array}{l}\text { Albitar (2015), Soliman (2013), } \\
\text { Chakroun \& Matoussi (2012), } \\
\text { Bhayani (2012) }\end{array}$ \\
\hline
\end{tabular}

Thus, based on the analysis of scientific literature, there could be various determinants of information disclosure on the internet: company's size, profitability and company's age.

\section{Research Methodology}

This study of information disclosure on the Internet and in the annual reports consisted of five main steps: 1) research sample selection; 2) selection of criteria for information disclosure index; 3) determinants of information disclosure on the Internet and measurement for those determinants; 4) creation of disclosure index for each company.

Analysis of annual reports provided by the companies on their websites was limited to analysis of annual reports provided by them within past 3 years since some authors as Jouirou \& Chenguel (2014) argues that company's practice of information disclosure in annual reports tend to remain relatively constant over the years. Correlation matrixes were concluded showing the relationship between the company's disclosure index and possible determinants of voluntary information disclosure. Spearman's rank correlation coefficient was calculated to measure the strength of association between research variables.

Research sample and sampling method. For this study a research sample was selected using a stratified random sampling method out of 1000 leading Lithuanian companies in 2014 with the highest earnings. A stratified sample was made up of different "layers" of the population, selecting random samples taken from different sectors, in proportion to the population. The study was based on data about "TOP 1000" Lithuanian Companies in 2014 with the highest earnings, which were collected by the State Tax Inspectorate Under the Ministry of Finance of the Republic of Lithuania or disclosed by the companies and provided in the periodical newsletter "Verslo zinios" for public use.

Stratified sample was selected in order to represent 1000 biggest Lithuanian companies with the highest earnings in terms of voluntary information disclosure and to assess voluntary information disclosure behavior of wider range companies having different characteristics and belonging to a wider income range compared with the samples of previous research on determinants of voluntary information disclosure.
To get a representative sample, random sampling was conducted and a stratified sample was selected.

The general population was divided into "layers" in proportion to existing population groups (different sectors). In the next step companies from each "layer" were selected, using simple random sampling method. Sample size was calculated following the example of previous studies that have applied this method, for the analysis of the companies' information disclosure, when the quantity of disclosed information was measured using the content analysis method (Mokhtar \& Mellette, 2013):

$$
S=\frac{P \cdot(1-P)}{\left(\frac{A^{2}}{Z^{2}}\right)+\frac{(P(1-P))}{N}} .
$$

Where: $\mathrm{S}$ - sample size; $\mathrm{N}$ - general population size; $\mathrm{P}$ - preliminary percentage of the population with the measured characteristics; A - significance level (for example, 0.05); $\mathrm{Z}$ - the number of standard deviations.

These formulas require prior determination of the " $\mathrm{P}$ " value. It is proposed to determine the " $\mathrm{P}$ " value by selecting a sample consisting of 30 companies to analyse the occurrence of the measured characteristic. In this study, the criterion of interest was the fact that the selected company should have a website. 30 companies were selected using random sampling and 28 of them had a website. For this reason, $\mathrm{P}=93$ percent, $\mathrm{Z}=1.96, \mathrm{a}=0.05$ and $\mathrm{N}=1000$ (1000 Lithuanian companies with the highest income in 2014). The required sample size, using the formula 1 , is equal to 92 .

However, according to other authors' practice when the sample size was chosen 10 percent higher, using this sampling method, the sample size was chosen 15 percent higher than required, in order to achieve greater accuracy (see Mokhtar \& Mellette, 2013), analysed sample included 106 companies.

There were selected 106 companies belonging to specific economic activities: B (Mining and quarrying), C (Manufacturing), D (Electricity, gas, steam and air conditioning supply), E (Water supply; sewerage, waste management and remediation activities), F (Construction), $\mathrm{G}$ (Wholesale and retail trade; repair of motor vehicles and motorcycles), $\mathrm{H}$ (Transportation and storage), I (Accommodation and food service activities), $\mathrm{J}$ (Information and communication activities), K (Financial and insurance activities), L (Real estate activities), M (Professional, scientific and technical activities), $\mathrm{N}$ (Administrative and support service activities), $\mathrm{P}$ (Education), Q (Human health and social work activities), R (Arts, entertainment and recreation activities) and $\mathrm{S}$ (Other service activities).

Voluntary information disclosure index and its criteria. Regarding information disclosure analysis the existing proxy of the voluntary information disclosure index was chosen. A new information disclosure index, on the basis of the indexes which previous foreign authors provide, was composed. Such a proxy was chosen because every situation is unique and a self - constructed disclosure index could best meet the needs of the research; also, $t$ is the best way to represent the research practice of voluntary information disclosure. 
According to disclosure indexes used in previous research and their structure (see Trabelsi et al., 2014; Ho \& Taylor, 2013; Gisbert \& Navallas, 2013; Binh, 2012; Soliman, 2013; Ahmadi \& Bouri, 2016; Broberg et al., 2010; Alfaraih \& Alanezi, 2011), a modified index was composed, selecting most frequently used index criterion according to their grouping in previous research. Index was adjusted to features and topics of by Lithuanian companies voluntarily provided information. In the line with previous research all companies' voluntarily provided information on their websites was divided into following groups: general and strategic information, historical information, company's financial results, main non - financial information, forward - looking information, managerial information and social responsibility information.

Method of index calculation. Given the numerous previous studies carried out by the foreign authors, in this study scope index has been calculated, which shows the amount of disclosed information measured by the number of disclosed criteria, assessing the presence or absence of particular information on companies' websites (see $2^{\text {nd }}$ equation).

$$
S C_{-} I_{i}=\frac{\sum_{j=1}^{60} S C_{i}}{60}
$$

Where: $\mathrm{SC}_{-} \mathrm{I}_{\mathrm{i}}$ - company's voluntary disclosure index calculated for a company $\mathrm{i} ; \mathrm{SC}_{\mathrm{i}}$ - evaluation of each disclosure criterion (value $=1$ if company $i$ discloses information on criterion $\mathrm{j}$, and 0 otherwise), 60 - number of criteria that could be disclosed (see appendix).

In addition to the voluntary information disclosure index, that measures scope of voluntary disclosed information, this study aimed to measure the voluntarily provided information in terms of quantity - quantitative index was calculated. Scaltrito $(2015,2016)$ appointed that previous authors used quantitative disclosure index to assess the quality of voluntarily provided information and quantitative disclosure index was calculated based on Urquiza et al. (2009) research. This index allows to analyze amount of company's voluntarily disclosed information on the Internet by assessing structural text units (words) of each information group (general and strategic information, historical financial information, non - financial information, forward - looking information, social responsibility information).

Content analysis also was used for the company's on the Internet provided text units with information about company's financial changes. This method was applied on the basis of Schumaker and Chen (2006) article that adjusted content analysis to appraise information disclosure in financial news articles. In this study voluntary disclosure indexes were calculated for all concluded information groups (general and strategic information, historical financial information, non-financial information, forward looking information, social responsibility information) by analogy in accordance with third formula provided below (see $3^{\text {th }}$ equation). The index values for each company's disclosed information group vary from 0 to 1 , where 1 means that the company provides a very high level of certain information compared to the amount of the same group information provided by other companies.

$$
Z_{-} B S_{i}=\frac{\left(b s_{i}-\min \right)}{(\max -\min )}
$$

Where: $\mathrm{Z}_{-} \mathrm{BS}_{\mathrm{i}}$ - voluntary information disclosure index of general and strategic information calculated for company $\mathrm{i} ; \mathrm{bs}_{\mathrm{i}}$ - word count of company's i voluntarily provided general and strategic information; max - the highest amount of words with general and strategic information provided among sample companies; min - the lowest amount of words with general and strategic information provided among sample companies.

In addition, in this study we proposed modification of previously used voluntary information disclosure indexes. A general voluntary disclosure index for each company was made, indicating the average level of all information groups' indexes, which were previously composed based on Urquiza et al. (2009). This index gives equal weight to all company's disclosed information groups (see $4^{\text {th }}$ equation) and asses not only the fact that information was disclosed but also the amount of disclosed information in a different information group.

$V I D_{-} Z_{-} I_{i}=\frac{Z_{-} B S_{i}+Z_{-} F_{i}+Z_{-} N_{i}+Z_{-} P_{i}+Z_{-} V_{i}+Z_{-} S O C_{i}}{6}$

Where: VID_Z_I $I_{i}$ - quantitative index of company's voluntary information disclosure, assessing the amount of the words voluntarily provided on the company's website; $Z_{-}$BS $, Z_{-} \_F_{i}, Z \_N_{i}, Z \_P_{i}, Z_{-} V_{i}$ and $Z \_S O C_{i}-$ disclosure indexes calculated for different disclosed information group: $\mathrm{Z}_{-} \mathrm{BS}_{\mathrm{i}}-$ general and strategic information, $\mathrm{Z}_{-} \mathrm{F}_{\mathrm{i}}-$ historical financial information, $Z_{-} \mathrm{N}_{\mathrm{i}}-$ non - financial information, $Z_{-} P_{i}$ - forward looking information, $Z_{-} V_{i}-$ managerial information, Z_SOC $\mathrm{i}_{\mathrm{i}}$ - social responsibility information.

Unwaged indexes were chosen because different weights given to separate information groups could distort results of the study (by giving weights to the different information group it would be focusing only on the interest of particular stakeholder without taking into account other company's interested parties).

There is a difference between lists of criterion, which were constructed for previously mentioned voluntary disclosure indexes (scope index and quantity index). By constructing VID_Z_I (information quantity index), nonverbal criteria covering numeric information: for example, information about price or contacts was excluded. Those criteria were used only to construct SC_I (information scope index).

Reliability was tested calculating Krippendorff's alpha coefficient, which was the above reference value for a reasonable level of reliability.

\section{Research Results and Discussion}

Firstly, the scope index (SC_I) for each company was calculated indicating how many criteria of the voluntarily disclosed information criterion list the company provides on its website. The maximum value of the index that could be gained by each company was equal 1 .

The research results revealed that the biggest value of the scope index reached by sample companies was equal 0,64 . The biggest number of disclosed criteria by the sample companies were 40 of 60 possible criteria (it was disclosed 64 percent of criteria that were included into voluntary information disclosure scope index). It means that none of the sample companies disclosed all criteria from 
information disclosure list. The Average of SC_I scope index was equal to 0.26 , meaning that the general level of voluntary information disclosure criterion among the sample companies is low. On average, there were 7 out of 14 possible general and strategic information criteria provided, 3 out of 13 social responsibility criteria, and 2 out of 9 non-financial information criteria.

Following the evaluation of disclosed information diversity by information groups, which was measured using SC_I index, the quantity index measuring disclosed words as text structural units was calculated for each information group: Z_BS - for general and strategical information; Z_N for non - financial information, $Z$ Z F for historical financial information, Z_P for forward looking information, $Z_{-} \mathrm{V}$ managerial information and Z_SOC - social responsibility information. The possible value of the word quantity index can vary from 0 to 1 , where 1 implies that the company provided the largest number of words with certain group information among the firms constituting the research sample. Meanwhile 0 shows that no certain group information was provided or the amount of disclosed information measured by words was the lowest among the research sample companies. Thus, this quantity index shows the level of voluntarily disclosed information compared with the company of the sample that has disclosed the biggest amount of certain group information voluntarily.

On the average, it was provided 26 percent of the general and strategical information amount disclosed by the leading company of the sample, which disclosed the largest number of words with certain information. Accordingly, on the average there was disclosed 10 percent of historical financial information compared with leading company in information disclosure. A significant part of the sample companies didn't disclose historical financial, non - financial, forward looking, managerial and social responsibility information on their websites.

It was counted an average of all quantity indexes for separate information groups. The biggest value of the average word quantity index including all information groups and counted for all companies was equal 0,46. It means that companies providing the biggest amount of particular information don't necessary disclose the biggest amount other group voluntary information.

By measuring the highest and lowest values of voluntarily disclosed information on companies' websites it was found that specific economic activities such as: D (Electricity, gas, steam and air conditioning supply), E (Water supply; sewerage, waste management and remediation activities), and $\mathbf{J}$ (Information and communication activities) reached the highest values of both SC_I and VID_Z_I index, in other words - disclosed highest amount and diversity of information voluntarily.

Information disclosure factor used in the correlation analysis shows, that there's a strong correlation between word count based index and information existence/nonexistence based index, whilst one index raises, the other does the same (see Table 3). Both indexes were used in the study to evaluate voluntary information disclosure, the fact of information disclosure itself and on the size of disclosed information (based on word count).
Table 3

Quantity Index (VID_Z_I) and Information Scope Index (SC_I) Correlation Matrix

\begin{tabular}{|l|l|l|r|r|}
\hline \multicolumn{2}{|c|}{} & VID_Z_I & SC_I \\
\hline \multirow{4}{*}{ Spearman's rho } & VID_Z_I & Correlation Coefficient & 1,000 &, $860^{* *}$ \\
\cline { 2 - 5 } & & Sig. (2-tailed) &. &, 000 \\
\cline { 2 - 5 } & & N & 92 & 92 \\
\cline { 2 - 5 } & SC_I & Correlation Coefficient &, $860^{* *}$ & 1,000 \\
\cline { 2 - 5 } & & Sig. (2-tailed) &, 000 &. \\
\cline { 2 - 5 } & & N & 92 & 92 \\
\hline
\end{tabular}

**. Correlation is significant at the 0.01 level (2-tailed).

Verification of hypothesis $\mathrm{H}_{1}$ about the companies' size influence on voluntary information disclosure.

$H_{1 A}$ : when the company size is based on income. Companies information disclosure index and income correlation analysis (see Table 4), using Spearmen correlation coefficient shows, that since the analyzed variables weren't spread out based on the normal distribution, there exists a small meaningful connection between the companies' income and general information disclosure word index (based on VID_Z_I), with 5 percent significance level $(p=0,035<0,05)$. Meanwhile the difference between information submission (existing/nonexisting information) SC_I index and companies' revenue is hardly existing $(0,19 \overline{6}<0,5)$ with only 10 percent significance level $(\mathrm{p}=0,061<0,1)$. Which means, that bigger (higher income earning) companies, give out a larger amount (word count) and diverse information (based on different categories and SC_I) index on the Internet website, compared to the smaller ones.

Table 4

Common Information Disclosure on the Companies' Websites and Income Correlation Matrix

\begin{tabular}{|l|l|l|r|r|r|}
\hline \multicolumn{3}{|c|}{} & VID_Z_I & SC_I & INCOME \\
\hline \multirow{5}{*}{} & VID_Z_I & $\begin{array}{l}\text { Correlation } \\
\text { Coefficient }\end{array}$ & 1,000 &, $860^{* *}$ &, $220^{*}$ \\
\cline { 2 - 6 } & & Sig. (2-tailed) &. &, 000 &, 035 \\
\cline { 2 - 6 } & & N & 92 & 92 & 92 \\
\cline { 2 - 6 } & Spearman's \\
rho & SC_I & $\begin{array}{l}\text { Correlation } \\
\text { Coefficient }\end{array}$ &, $860^{* *}$ & 1,000 &, 196 \\
\cline { 2 - 6 } & & Sig. (2-tailed) &, 000 &. &, 061 \\
\cline { 2 - 6 } & & N & 92 & 92 & 92 \\
\cline { 2 - 6 } & INCOME & $\begin{array}{l}\text { Correlation } \\
\text { Coefficient }\end{array}$ &, $220^{*}$ &, 196 & 1,000 \\
\cline { 2 - 6 } & & Sig. (2-tailed) &, 035 &, 061 & 92 \\
\cline { 2 - 6 } & & N & 92 & 92 &. \\
\hline
\end{tabular}

**. Correlation is significant at the 0.01 level (2-tailed). Correlation is significant at the 0.05 level (2-tailed).

The connection between the company's common information disclosure index and the company's size can be explained using agents, legitimacy and shareholders theories. On the basis of agent theory, agent's spending's increase with the growth of external capital, which in return increases with the growth of the company. The theoretical explanation for this is the fact that the bigger companies' attempt to disclose more information to reduce information asymmetry and capital production costs (see Broberg et al., 2010; Zadeh \& Eskandari, 2012). On the basis of legitimacy theory, companies existence depends on how society, where it's operating accepts it. Bigger companies are more noticeable by the society, so in order to maintain their reputation, they are likely to disclose more information (see Juhmani, 2014). Based on the shareholders theory, the 
bigger the company is, the more people are interested in it and because of that bigger companies usually feel more pressure by the interest groups, which results in more disclosed information.

Survey results coincide with most of previous author insights. Positive connections between voluntary information disclosure on the internet and company size (assessed in property, income, employees), was discovered by the following authors: Basuony \& Mohamed (2014), Pozniak (2015), Barac et al. (2014), analyzing both financial and non-financial information disclosure on the internet websites, positive correlation was discovered between information disclosure and company size by Ghasempour \& Yusof (2014), Hossain et al. (2012).

$H_{l B}$ : when the company size is based on the number of employees. Results of the survey show, that evaluating information disclosure, while using the information scope index (SC_I), overall information disclosure and company size based on number of employees are directly correlated (see Table 5). Given that the survey variables, such as number of employees, aren't spread out on the normal distribution, ranked Spearman correlation coefficient is used. The data is not distributed normally, because the sample companies are very different in their size, however most of the companies have less than 250 workers.

Table 5

Correlation Matrix of Relation between Information Disclosure Index and Number of Companies' Employees

\begin{tabular}{|l|l|l|r|r|r|}
\hline \multicolumn{3}{|c}{} & VID_Z_I & SC_I & D_SK \\
\hline \multirow{5}{*}{} & VID_Z_I & $\begin{array}{l}\text { Correlation } \\
\text { Coefficient }\end{array}$ & 1,000 &, $860^{* *}$ &, 159 \\
\cline { 2 - 6 } & & Sig. (2-tailed) &. &, 000 &, 129 \\
\cline { 2 - 6 } & & N & 92 & 92 & 92 \\
\cline { 2 - 6 } & SC_I & $\begin{array}{l}\text { Correlation } \\
\text { Coefficient } \\
\text { rho }\end{array}$ &, $860^{* *}$ & 1,000 &, $211^{*}$ \\
\cline { 2 - 6 } & & Sig. (2-tailed) &, 000 &. &, 043 \\
\cline { 2 - 6 } & & N & 92 & 92 & 92 \\
\cline { 2 - 6 } & D_SK & $\begin{array}{l}\text { Correlation } \\
\text { Coefficient }\end{array}$ &, 159 &, $211^{*}$ & 1,000 \\
\cline { 2 - 6 } & & Sig. (2-tailed) &, 129 &, 043 &. \\
\cline { 2 - 7 } & & $\mathrm{N}$ & 92 & 92 & 92 \\
\hline
\end{tabular}

**. Correlation is significant at the 0.01 level (2-tailed). *. Correlation is significant at the 0.05 level (2-tailed).

There exists a very small yet important connection $(0,211<0,5)$ between the companies' information disclosure index SC_I assessing information's existence or nonexistence and number of companies' employees, whilst having 5 percent significance level $(\mathrm{p}=0,043<0,05)$. Such survey results coincide with the previous author, such as Jouirou and Chenguel (2014) results on financial and nonfinancial information disclosure and company size, based on number of employees having positive connections. Just like with the case on hypothesis on income and companies financial and non-financial information disclosure, such connection can be explained with agents, legitimacy and shareholder's theory statements. Meanwhile assessing information disclosure based on word index (VID_Z_I) connection between company size, assessed by number of employees and existence of information disclosure wasn't discovered $(\mathrm{p}=0,129>0,05$, more than 5 percent significance level).
There was no significant relation between disclosed information groups that were included into voluntary disclosure index (general and strategical information, historical financial information, managerial information) and company size, that was described as company's revenue and number of employees.

There was found significant relation between social responsibility information disclosure and company's size, measured as number of employees and between main non financial information and company's revenue. Research results showed that (see 6 Table) there is week $(0,245<0,5$ and $0,216<0,5)$ statistically significant relation $(0,018$ and $0,039<0,05$, when level of significance is equal 5 percent) (using Spearman's correlation coefficient) between both SC_SOC and SOC index and company's size measured as number of company's employees.

This result showed, that larger companies provide larger amount and more different information than the smaller ones. Result of this research differs from Juhmani (2014) study results when there was found no significant relation between company's size and amount of voluntarily disclosed information. This research showed the same results as research conducted by Smirnova \& Rudzioniene (2012), which showed that companies, which are getting more revenue and having more employees are additionally disclosing more social responsibility information.

Table 6

Correlation Matrix of Relation between Social

Information Disclosure on the Companies' Websites and Number of Companies' Employees

\begin{tabular}{|c|c|c|c|c|c|}
\hline & & & $\mathrm{SOC}$ & SC_SOC & D_SK \\
\hline \multirow{9}{*}{$\begin{array}{l}\text { Spearman's } \\
\text { rho }\end{array}$} & SOC & $\begin{array}{l}\text { Correlation } \\
\text { Coefficient }\end{array}$ & 1 & ,797** & ,216 \\
\hline & & Sig. (2-tailed) & & 0 & 0,039 \\
\hline & & $\mathrm{N}$ & 92 & 92 & 92 \\
\hline & SC_SOC & \begin{tabular}{|l|} 
Correlation \\
Coefficient
\end{tabular} &, $797^{* *}$ & 1 &, $245^{*}$ \\
\hline & & Sig. (2-tailed) & 0 & & 0,018 \\
\hline & & $\mathrm{N}$ & 92 & 92 & 92 \\
\hline & D_SK & $\begin{array}{l}\text { Correlation } \\
\text { Coefficient }\end{array}$ & ,216* &, $245^{*}$ & 1 \\
\hline & & Sig. (2-tailed) & 0,039 & 0,018 & \\
\hline & & $\mathrm{N}$ & 92 & 92 & 92 \\
\hline
\end{tabular}

**. Correlation is significant at the 0.01 level (2-tailed). *. Correlation is significant at the 0.05 level (2-tailed).

Results of this research are similar to the results of research conducted by Rudzioniene and Petraskaite (2014), because research results and significance of relation differs depending on the measure chosen to assess company's size: company's revenue, number of employees and company's asset.

Testing hypothesis $\mathrm{H}_{2}$, which suggest that a company's profitability determinates voluntary information disclosure on the Internet.

Correlation analysis of a company's voluntary disclosure indexes and company's profitability (see Table 7) showed that there is no significant relation between general voluntary information disclosure index and a company's profitability using both the word quantity index (VID_Z_I), which indicates the number of disclosed words $(\mathrm{p}=0,606>0,05)$, and information scope index (SC_I), which 
indicates it was or not certain information disclosed $(\mathrm{p}=0,799>0,05)$.

Thus, the second hypothesis about the relationship between a company's profitability and general (financial and non-financial information voluntary disclosure) voluntary information disclosure was denied.

Table 7

Correlation Matrix of Information Disclosure on Websites and Companies' Profitability

\begin{tabular}{|l|l|l|r|r|r|}
\hline \multicolumn{2}{|c|}{} & VID_Z_I & SC_I & ROS \\
\hline $\begin{array}{l}\text { Spearman' } \\
\text { s rho }\end{array}$ & VID_Z_I & $\begin{array}{l}\text { Correlation } \\
\text { Coefficient }\end{array}$ & 1,000 &, $860^{* *}$ &,- 055 \\
\cline { 2 - 6 } & & Sig. (2-tailed) &. &, 000 &, 606 \\
\cline { 2 - 6 } & & N & 92 & 92 & 92 \\
\cline { 2 - 6 } & SC_I & $\begin{array}{l}\text { Correlation } \\
\text { Coefficient }\end{array}$ &, $860^{* *}$ & 1,000 &,- 027 \\
\cline { 2 - 6 } & & Sig. (2-tailed) &, 000 &. &, 799 \\
\cline { 2 - 6 } & & N & 92 & 92 & 92 \\
\cline { 2 - 6 } & ROS & $\begin{array}{l}\text { Correlation } \\
\text { Coefficient }\end{array}$ &,- 055 &,- 027 & 1,000 \\
\cline { 2 - 6 } & & Sig. (2-tailed) &, 606 &, 799 &. \\
\cline { 2 - 6 } & & N & 92 & 92 & 92 \\
\hline
\end{tabular}

**. Correlation is significant at the 0.01 level (2-tailed).

Results of this research are similar with results of previous research which were initiated by Ghasempour and Yusof (2014), Hossain et al. (2012), Alali and Romero (2012), who analysed general information disclosure on the internet (financial and non - financial information) and there was no significant relation between information disclosure and a company's profitability.

Testing of $\mathrm{H}_{3}$ hypothesis about a company's age influence to voluntary information disclosure on a company's website.

Correlation analysis of the relationship between information disclosure and company's age (see Table 8) using Spearman's correlation coefficient found no significant relationship between company's age and information disclosure on company's website $(p=0,799>0,05$, case of VID_Z_I index, and $\mathrm{p}=0,355>0,05$, case of SC_I). These results are similar to the results of studies initiated by other authors such as Hannon (2014) and Juhmani (2014), which analyzed determinants of financial and social responsibility information disclosure on the companies' websites.

Table 8

Correlation Matrix of Relationship between Information Disclosure on Companies' Websites and Companies' Age

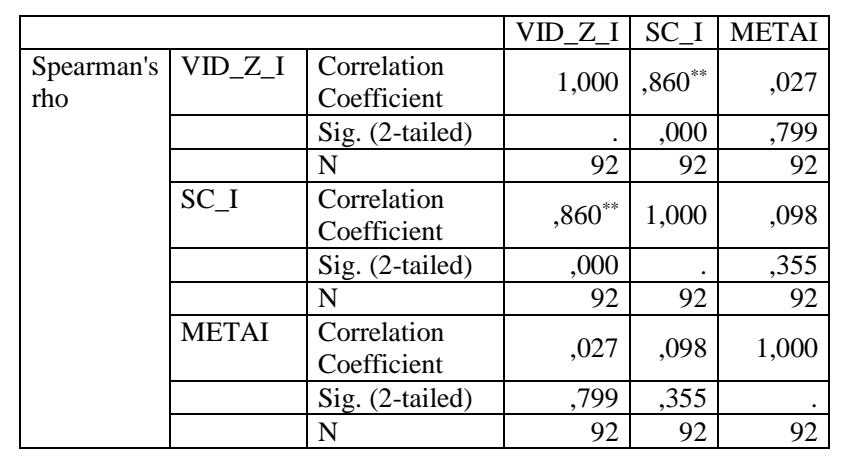

**. Correlation is significant at the 0.01 level (2-tailed).
According to Collis (2012), environment, in which small companies are working, differs from environment and circumstances, in which large companies are doing their businesses. Large companies have different interest parties (not only investors but also suppliers, consumers and other) than small companies. Because of that reason aims, purpose and determinants of decision to voluntarily disclose information in small and large companies are different.

In future studies the relationship between a company's voluntary information disclosure and profitability could be analyzed in different companies depending on their size groups.

Based on the results of previous research which suggested that the amount of voluntarily disclosed information does not mean greater quality of disclosed information (quantity doesn't go hand in hand with quality), there should be conducted (initiated) new research on the quality of voluntarily disclosed information. There is a wide range of possibilities for further research, there could be analyzed more different determinants that could possible determinate voluntary information disclosure, there could be chosen expert evaluation or evaluation of interested parties (stakeholders), in order to get more detailed information, which information for which interested parties is most important, to know which factors determine that companies chose to disclose more information that other companies.

\section{Conclusions}

Analysis of scientific literature showed that there is no common (general) theory that is adjusted to voluntary information disclosure analysis. Mostly used theories in voluntary information disclosure literature: agent theory, legitimacy theory, stakeholders' theory, signaling theory and capital cost theory. According to previous research analysis there is no common opinion about factors, which are determining voluntary information disclosure on the Internet. In Lithuania, there is no enough studies, which are analyzing practice of voluntary information disclosure and factors which are determining that type of disclosure.

Information provision index SC_I (information is provided/not provided) revealed that no company has provided the maximum number of criteria (60). Approximately, 7 out of 14 (general \& strategic information), 3 out of 13 (social responsibility), 1 or 2 (other groups of information) criteria are provided, which indicates a low information provision level among sample companies. Quantitative index (VID_Z_I) displayed quite similar results. On average, companies provide about 26 percent general and strategic information, while other types of information provision do not exceed 10 percent. The companies' average of VID_Z_I index, which involves provision of different group information, is equal to 0,07 . This means that immense differences between sample companies' voluntary information disclosure exists. Furthermore, the general level of voluntary information provision is low, compared to the sample companies, which provided the most information.

Findings of this article revealed that an information asymmetry problem in smaller companies can be seen at a more pronounced level than in bigger ones. Correlation analysis using Spearman rank correlation coefficient revealed a statistically significant weak connection between 
Kristina Kundeliene, Agne Stepanauskaite. Information Disclosure and its Determinants on Lithuanian Companies'...

the size of company (evaluation factors were the number of employees as well as income) and its' voluntary information disclosure index exists. Moreover, there is a link among companies' income and its' voluntary information provision assessed by the word index as well, even though the number of employees and average of voluntary information disclosure index had shown no obvious connection. It means that the research results are impacted by the evaluation methods of information disclosure as well as factors measurement criterion (number of employees, income or assets). Larger companies tend to provide more diverse information (more criteria from the information provision index list), even though information variability does not indicate a more significant number of words. Furthermore, a weak statistically significant link between companies' social information disclosure online and its' number of employees was found. Larger companies with more employees provide a larger amount of social responsibility information. Thus, larger companies are more interested in reducing informational asymmetry between them and their interest groups than the smaller ones. This connection can be explained because larger companies have more stakeholder groups whose demands must be satisfied, and these enterprises are more noticeable. Due to this fact, they provide more information in order to improve reputation and meet the regulatory requirements. Meanwhile, profitability and companies' age do not have any impact on information disclosure because no significant connection was identified. Consequently company's performance and age have no significant influence on their willingness to disclose more information and reduce information asymmetry.

There is still a need for further investigation of possible determinants of voluntary information disclosure. It could be chosen interested parties evaluation or evaluation of the experts in order to get more detailed information regarding most important determinants.

\section{Appendix}

Information Items of Scope Index

\begin{tabular}{|c|c|}
\hline Information group & Information items \\
\hline I. General and strategic information & $\begin{array}{l}\text { 1. a brief description of the company's history } \\
\text { 2. business culture and values } \\
\text { 3. mission and vision } \\
\text { 4. strategy and goals of the company } \\
\text { 5. the competitive environment } \\
\text { 6. general business description } \\
\text { 7. description of development projects } \\
\text { 8. organizational structure } \\
\text { 9. the main markets } \\
\text { 10. products/services } \\
\text { 11. business events } \\
\text { 12. discussion about industry trends } \\
\text { 13. contact information } \\
\text { 14. awards }\end{array}$ \\
\hline II. Historical information on company's financial results & $\begin{array}{l}\text { 1. turnover and its growth } \\
\text { 2. investments } \\
\text { 3. profitability ratios } \\
\text { 4. activity ratios } \\
\text { 5. liquidity ratios } \\
\text { 6. debt ratios } \\
\text { 7. share price } \\
\text { 8. other financial information }\end{array}$ \\
\hline III. Main non - financial information & $\begin{array}{l}\text { 1. number of employees } \\
\text { 2. employee gender } \\
\text { 3. the added value generated by the employee } \\
\text { 4. market share } \\
\text { 5. price of the product/service } \\
\text { 6. the volume of sales and its growth } \\
\text { 7. consumers, collaboration } \\
\text { 8. customer satisfaction, retention, loyalty } \\
\text { 9. other information }\end{array}$ \\
\hline IV. Forward - looking information & $\begin{array}{l}\text { 1. forecasted market share } \\
\text { 2. cash flow forecast } \\
\text { 3. R\&D forecast } \\
\text { 4. profit forecast } \\
\text { 5. forecast of sales volume } \\
\text { 6. revenue forecast } \\
\text { 7. forecast on capital costs } \\
\text { 8. new investments } \\
\text { 9. factors affecting the activities of the company } \\
\text { 10. information about the development of a new product }\end{array}$ \\
\hline V. Managerial information & $\begin{array}{l}\text { 1. academic and professional qualification and experience of the CEO, CFO } \\
\text { 2. information on board members } \\
\text { 3. comments, analysis of the changes in the company provided by CEO } \\
\text { 4. ownership structure/concentration } \\
\text { 5. other management information }\end{array}$ \\
\hline VI. Social responsibility information & $\begin{array}{l}\text { 1. participation in social projects } \\
\text { 2. support or charity provision } \\
\text { 3. environmental policy }\end{array}$ \\
\hline
\end{tabular}




\begin{tabular}{|l|l|}
\hline \multicolumn{1}{|c|}{ Information group } & \multicolumn{1}{c|}{ Information items } \\
\hline & 4. environmental management system \\
& 5. development of environmentally friendly products \\
& 6. implemented environmental programs \\
& 7. protection of human rights \\
& 8. employee welfare policy disclosure \\
& 9. employees safety and health policy \\
& 10. information on accidents in the workplace \\
& 11. system of qualification and motivation of employees \\
& 12. codes of ethics \\
\hline & 13. product safety information \\
\hline TI. Social responsibility information & 14. implemented quality systems \\
\hline
\end{tabular}

\section{References}

AbuGhazaleh, N. M., Qasim, A., \& Roberts, C. (2012). The Determinants of Web - Based Investor Relations Activities by Companies Operating In Emerging Economies: The Case Of Jordan. Journal of Applied Business Research, 28 (2), 209-226. https://doi.org/10.19030/jabr.v28i2.6842

Ahmadi, A., \& Bouri, A. (2016). The impact of financial safety act and corporate governance on the level of financial disclosure Case of Tunis Stock Exchange firms. International Journal of Law and Management, 58 (6), $618-633$. https://doi.org/10.1108/IJLMA-06-2015-0030

Alali, F., \& Romero, S. (2012). The use of the Internet for corporate reporting in the Mercosur (Southern common market): The Argentina case. Advances in Accounting, 28 (1), 157-16. https://doi.org/10.1016/j.adiac.2012.03.009

Albitar, K. (2015). Firm Characteristics, Governance Attributes and Corporate Voluntary Disclosure: A Study of Jordanian Listed Companies. International Business Research, 8 (3), 1-10. https://doi.org/10.5539/ibr.v8n3p1

Alfaraih, M. M., \& Alanezi, F. S. (2011). Does voluntary disclosure level affect the value relevance of accounting information? Accounting \& Taxation, 3 (2), 65-84.

Alhazaimeh, A., Palaniappan, R., \& Almsafir, M. (2014). The directions of causality between the voluntary disclosure and company performances among listed Jordanian companies. Journal of advanced social research, 9 (4), 01-14. Available from internet: http://www.sign-ific-ance.co.uk/index.php/JASR/article/view/815

Barac, A. Z. (2012). Voluntary disclosure of cash flows information and company's characteristics: evidence from the Croatian capital market. Croatian Operational Research Review, 3, 192-202. Available from internet: http://hrcak.srce.hr/file/142459

Barac, Z., Granic, M., \& Vuko, T. (2014). The Determinants of Voluntary Disclosure in Croatia. International Journal of Social, Behavioral, Educational, Economic, Business and Industrial Engineering, 8(4), 1057-1063.

Basouny, M. A. K., \& Mohamed, E. K. A. (2014). Determinants of Internet Financial Disclosure in GCC. Asian Journal of Finance \& Accounting, 6 (1), 70-89. https://doi.org/10.5296/ajfa.v6i1.5085

Bhayani, S. (2012). Association between Firm-Specific Characteristics and Corporate Disclosure: The Case of India. International Conference on Business, Economics, Management and Behavioral Sciences, 479-482. Available from internet: http://psrcentre.org/images/extraimages/24.\%200112051.pdf.

Binh, T. Q. (2012). Voluntary disclosure information in the annual reports of non financial listed companies: the case of Vietnam. Journal of Applied Economics and Business Research, 2 (2), 69-90. Available from internet: http://www.aebrjournal.org/uploads/6/6/2/2/6622240/2._binh-2.pdf.

Borbolla, A. G., Larrịn, M., \& Lopez, R. (2005). Empirical Evidence Concerning SMEs' Corporate Websites: Explaining Factors, Strategies and Reporting. The International Journal of Digital Accounting Research, 5(10), 171-202.

Bozcuk, E. A., Aslan S., \& Arzova, B. S. (2011). Internet financial reporting in Turkey. EuroMed Journal of Business, 6 (3), 313-323. https://doi.org/10.1108/14502191111170141

Broberg, P., Tagesson, T., \& Collin, S. O. (2009). What explains variation in voluntary disclosure? A study of the annual reports of corporations listed on the Stockholm Stock Exchange. Journal of Management \& Governance, $14,351$. https://doi.org/10.1007/s10997-009-9104-y

Bruslerie, H., \& Gabteni, H. (2014). Voluntary disclosure of financial information by French firms. Does the introduction to IFRS matter. Advances in Accounting, 30 (2), 367-380. https://doi.org/10.1016/j.adiac.2014.09.016

Carroll, A. (2011). Media Relations and Corporate Social Responsibility. In Jennifer Bartlett, Uyvind Ihlen, Steve May (Eds.): The handbook of communication and corporate social responsibility (pp. 423-444). Malden, MA: Wiley Blackwell. https://doi.org/10.1002/9781118083246.ch21

Cassar, G., Ittner, Ch. D., Cavalluzo, K. S. (2015). Alternative Information Sources and Information Asymmetry Reduction: Evidence from Small Business Debt. Journal of Accounting and Economics, 59 (2/3), 242-263. https://doi.org/10.10 16/j.jacceco.2014.08.003 
Kristina Kundeliene, Agne Stepanauskaite. Information Disclosure and its Determinants on Lithuanian Companies'...

Ceustermans, S., \& Breesch, D. (2017). Determinants of Voluntary Disclosure of Sales in Small Private Companies in Belgium. Journal of International Financial Management \& Accounting, 28 (2), 172-204. https://doi.org/10. $1111 /$ jifm. 12055

Collis, J. (2012). Determinants of voluntary audit and voluntary full accounts in micro- and non-micro small companies in the UK. Accounting and business research, 42 (4), 441-468. https://doi.org/10.1080/00014788.2012.667969

Dagiliene, L. (2009). The role of voluntary disclosed information in financial valuation. Social Research 17(3), 18-27. Available from internet: http://vddb.library.lt/fedora/get/LT-eLABa-0001:J.04 2009 ISSN_1392-3110.N_3_17.PG _18-27/ DS.002.1.01.ARTIC.

Dagiliene, L. (2010). The research of corporate social responsibility disclosures in annual reports. Inzinerine EkonomikaEngineering Economics, 21 (2), 197-204.

Dagiliene, L., \& Bruneckiene, J. (2010). Savanoriskai atskleidziamos informacijos vaidmuo įmoniu socialines atsakomybes aspektu. Economics and Management, 15, 451-456. Available from internet: http://etalpykla.lituanistikadb.lt /fedora/objects/LT-LDB-0001:J.04 2010 1367178035818/datastreams/DS.002.0.01.ARTIC/content.

Dagiliene, L., \& Gokiene, R. (2011). Valuation of corporate social responsibility reports. Economics and Managament, 16, 5-6. Available from internet: http://etalpykla.lituanistikadb.lt/fedora/objects/LT-LDB-0001:J.04 2011 1367176 794480/datastreams/DS.002.1.01.ARTIC/content.

Dagiliene, L., Leitoniene, S., Grencikova, A. (2014). Increasing Business Transparency by Corporate Social Reporting: Development and Problems in Lithuania. Inzinerine Ekonomika-Engineering Economics, 25(1), 54-61. https://doi.org/10.57 55/j01.ee.25.1.2356

Feleagă, N., \& Dragomir, V. D. (2012). The Evolution of Corporate Governance and Accounting in a Sustainability Context. Proceedings of the 8th European Conference on Management Leadership and Governance. 170-177.

Gamerschlag, R., Moller, K., \& Verbeeten, F. (2011). Determinants of voluntary CSR disclosure: empirical evidence from Germany. Review of Managerial Science, 5, 233 - 262. https://doi.org/10.1007/s11846-010-0052-3

Ghasempour, A., \& Yusof, M. A. M. (2014). The Effect of Fundamental Determinants on Voluntary Disclosure of Financial and Nonfinancial Information: The Case of Internet Reporting on the Tehran Stock Exchange. The International Journal of Digital Accounting Research, 14, 37-56. https://doi.org/10.4192/1577-8517-v14_2

Gisbert, A., \& Navallas, B. (2013). Association between voluntary disclosure and corporate governance in the presence of severe agency conflicts. Advances in Accounting, 29 (2), 286-298.

https://doi.org/10.1016/j.adiac.2013.07.001

Hamrouni, A., Benkraiem, R., \& Karmani, M. (2017). Voluntary information disclosure and sell-side analyst coverage intensity. Review of Accounting and Finance, 16 (2), 260-280. https://doi.org/10.1108/RAF-02-2015-0024

Hannon, A. (2014). The E-Voluntary Disclosure of Financial Information, a Jordanian Phenomenon. Academy of Contemporary Research Journal. Available from internet: http://aocrj.org/wp-content/uploads/2015/03/0270303 2015Duba-Final-Formatted2.pdf.

Ho, P. L., \& Taylor, G. (2013). Corporate governance and different types of voluntary disclosure. Pacific Accounting Review, 25 (1), 4-29. https://doi.org/10.1108/01140581311318940

Hossain, M., Momin, M. A., \& Leo, S. (2012). Internet financial reporting and disclosure by listed companies: further evidence from an emerging country. Corporate ownership \& control, 9 (4), 351-366. https://doi.org/10.22 495/cocv9i4c3art6

Jouirou, M., \& Chenguel, M. B. (2014). The Determinants of Voluntary Disclosure in Tunisia: A Study of the Firms Listed in the Tunisian Stock Exchange. Journal Business Management Research, 4, 86-97.

Juhmani, O. (2014). Determinants of Corporate Social and Environmental Disclosure on Websites: The Case of Bahrain. Universal Journal of Accounting and Finance, 2 (4), 77-87.

Kilic, A., Uyar, A., \& Bayyurt, N. (2013). Association between firm characteristics and corporate voluntary disclosure. Intangible Capital, 9(4), 1080-1112.

Kitching, J., Kasperova, E., Blackburn, R., \& Collis, J. (2011). Small company abbreviated accounts: A regulatory burden or a vital disclosure? Edinburgh: Institute of Chartered Accountants in Scotland. Available from internet: http://eprints.kingston.ac.uk/id/eprint/19292.

Legenzova, R. (2008). An assessment of interaction between ownership structure and voluntary financial disclosure of Lithuanian corporates. Economics and Management, 13, 48-54.

Legenzova, R. (2009). Entity's information disclosure: a model. Management of Organizations: Systematic Research, 52, $35-47$.

Legenzova, R., \& Jovaisaite, A. (2014). An analysis of information disclosure on corporate websites in Lithuania. Science and Studies of Accounting and Finance: Problems and Perspectives, 9 (1), 102-115.

Leitoniene, S., \& Sapkauskiene, A. (2012). Socialines informacijos kaip Lietuvos imoniu etiskos elgsenos kriterijaus analize. Economcs and Management, 17 (3), 836-843. https://doi.org/10.5755/j01.em.17.3.2091 
Leitoniene, S., \& Sapkauskiene, A. (2015). Quality of Corporate Social Responsibility Information. Procedia - Social and Behavioural Sciences, 213 (1), 334-339. https://doi.org/10.1016/j.sbspro.2015.11.547

Mokhtar, E. S., \& Mellett, H. (2013). Competition, corporate governance, ownership structure and risk reporting. Managerial Auditing Journal, 28 (9), 838-865. https://doi.org/10.1108/MAJ-11-2012-0776

Nandi, S., \& Ghosh, S. K. (2012). Corporate governance attributes, firm characteristics and the level of corporate disclosure: Evidence from the Indian listed firms. Decision Science Letters, 2 (1), 45-58. https://doi.org/10.5267/j.ds1.2012.10.004

Nilehn, P. (2014). Determinants of voluntary disclosure in Swedish corporate annual reports. Master's thesis, Uppsala University.

Potrich, R., Sabadin, M. \& Angonese, R. (2017). Companies Potentially Polluting: Determinants Affecting the Voluntary Disclosure of Environmental Information. Revista Ambiente Contabil, 9 (2), 41-59.

Pozniak, L. (2015). Unregulated Markets and Internet Financial Communication: Qualitative and Quantitative Approaches. Review of Business \& Finance Studies, 6 (1), 109-120.

Prince, J., \& Dwivedi, N. (2013). A third dimension to understanding voluntary disclosures. Journal of Business Strategy, 34 (4), 48-54. https://doi.org/10.1108/JBS-11-2012-0063

Rudzioniene, K., \& Petraskaite, V. (2014). The determinants of disclosure of corporate social responsibility which is presented in the financial information on the internet. Science and Studies of Accounting and Finance: Problems and Perspectives 9 (1), 204-212.

Scaltrito, D. (2015). Assessing Disclosure Quality: A Methodological Issue. Journal of Modern Accounting and Auditing, 11 (9), 466-475. https://doi.org/10.17265/1548-6583/2015.09.004

Scaltrito, D. (2016). Voluntary disclosure in Italy Firm-specific determinants an empirical analysis of Italian listed companies. Euromed Journal of Business, 11 (2), 272-303. https://doi.org/10.1108/EMJB-07-2015-0032

Schumaker, P. R., \& Chen, H. (2009). Textual Analysis of Stock Market Prediction Using Breaking Financial News: The AZFinText System. Artificial Intelligence Lab, Department of Management Information Systems, 27(2), Article Number: 12.

Siala, H. G., Sellami, Y. M., \& Fendri, H. B. (2014). Determinants of voluntary web-based disclosure: A comparison of the united kingdom and its former colony, New Zealand. International Journal of Accounting and Economics Studies, 2(2), 100-110. https://doi.org/10.14419/ijaes.v2i2.3668

Smirnova, R., \& Rudzioniene, K. (2012). Imonių socialines atsakomybes finansinese ataskaitose atskleidimo veiksniai. Buhalterines apskaitos teorija ir praktika. Lietuvos buhalterines apskaitos tyrejų ir svieteju asociacija, 12, 31 - 40.

Soliman, M. (2013). Firm Characteristics and the Extent of Voluntary Disclosure: The Case of Egypt. Research Journal of Finance and Accounting, 17 (4), 71-80. https://doi.org/10.2139/ssrn.2311005

Sommer, F., Klink, J., Senki, S., \& Hartmann, M. (2014). Determinants of Web-based CSR Disclosure in the Food Industry. Proceedings in food system dynamics, 18-25.

Trabelsi, S., Debreceny, R., \& Lymer, L. (2014). An empirical examination of corporate websites as a voluntary disclosure medium. International Journal of Applied Decision Sciences (IJADS), 7 (1), 1-32. https://doi.org/10.1504/IJADS.20 14.058038

Urquiza, B., Navarro, M. C. A., \& Trombetta, M. (2009). Disclosure indices design: does it make a difference? Revista de Contabilidad, 12 (2), 253-277. https://doi.org/10.1016/S1138-4891(09)70008-1

Zadeh, F. O., \& Eskandari, A. (2012). Looking Forward to Financial Risk Disclosure Practices by Malaysian Firms. Australian Journal of Basic and Applied Sciences, 6(8), 208-214.

Zhang, B. Z., \& Niu, S. J. (2015). Study on Voluntary Information Disclosure and Stock Price Synchronicity: Evidence from Chinese Listed Companies. Proceedings of the 2015 International Conference on Management Science and Management Innovation. AEBMR-Advances in Economics Business and Management Research, 6, 501-507. https://doi.org/10.2991/msmi-15.2015.93

Zhang, H. J., \& Zhang, X. (2014a). An Analysis of Factors Associated with Voluntary Disclosure of Internal Control Information of Listed Companies in Our Country. International Conference on Information Technology and Management Engineering (ITME 2014), 305-309.

Zhang, Z., \& Zhang, J. (2014b). Analysis on Voluntary Disclosure of Accounting Information for Listed Companies in China. International Business and Management, 9 (1), 143-148.

The article has been reviewed.

Received in December, 2016; accepted in October, 2018. 